\title{
EFEKTIVITAS PENERIMAAN PESERTA DIDIK BARU (PPDB) MENGGUNAKAN SISTEM ZONA DALAM PEMERATAAN DAN PENINGKATAN KUALITAS PENDIDIKAN (STUDI KASUS PADA SMPN KECAMATAN TEMANGGUNG)
}

\author{
Hidayah Setiyanti \\ Program Pasca Sarjana \\ Universitas Muhammadiyah Yogyakarta \\ E-mail: hidayahsetyanti@gmail.com
}

\begin{abstract}
Abstrak
Penelitian ini bertujuan untuk: 1) mengetahui alasan Penerimaan Peserta Didik Baru (PPDB) menggunakan sistem zona di Kecamatan Temanggung. 2) mengetahui penerapan Penerimaan Peserta Didik Baru (PPDB) dengan sistem zona di Kecamatan Temanggung. 3) mengidentifikasi efektivitas Penerimaan Peserta Didik Baru (PPDB) dengan sistem zona di Kecamatan Temanggung dalam pemerataan dan peningkatan kualitas pendidikan. Pendekatan yang digunakan adalah metode pendekatan kualitatif dengan menggunakan desain penelitian studi kasus. Lokasi penelitian ini bertempat di Sekolah Menengah Pertama (SMP) di Kecamatan Temanggung. Pada penelitian ini, peneliti akan menggunakan snowball sampling. Sedangkan teknik pengumpulan data yang digunakan yakni observasi, wawancara dan dokumentasi. Adapun analisis data yang dilakukan yaitu reduksi data, penyajian data dan penarikan kesimpulan verifikasi.Hasil penelitian ini menujukkan bahwa Penerimaan Peserta Didik Baru (PPDB) menggunakan sistem zona diharapkan mampu mengatasi masalah kesenjangan kualitas pendidikan di kota dan di pinggir kota. Disisi lain timbul masalah ketika pada kenyataannya di Kecamatan Temanggung terdapat 6 SMP Negeri.
\end{abstract}

Kata kunci: penerimaan peserta didik baru, sistem zonasi, pemerataan dan peningkatan kualitas pendidikan

\begin{abstract}
This study aims to: 1) find out the reasons for New Student Admission (PPDB) using the zone system in Temanggung District. 2) knowing the application of New Student Admission (PPDB) with a zone system in Temanggung District. 3) identifying the effectiveness of New Student Admissions (PPDB) with the zone system in Temanggung Subdistrict in terms of equity and improving the quality of education. The approach used is a qualitative approach using a case study research design. The location of this study took place in Junior High Schools (SMP) in Temanggung District. In this study, researchers will use snowball sampling. While the data collection techniques used are observation, interview and documentation. The data analysis was carried out namely data reduction, data presentation and conclusion of verification. The results of this study show that New Student Admission (PPDB) using the zone system is expected to be able to overcome the problem of the gap in the quality of education in the city and on the edge of the city. On the other hand there were problems when in reality there were 6 Public Middle Schools in Temanggung District.
\end{abstract}

Keywords:new student acceptance, zoning system, equity and improving the quality of education

\section{Info Artikel}

Diterima Januari 2019, disetujui Februari 2019, diterbitkan Juni 2019 


\section{PENDAHULUAN}

Salah satu yang termasuk dari manajemen sekolah yakni manajemen peserta didik. Manajemen sekolah sendiri terdiri dari manajemen keuangan, manajemen pembelajaran, manajemen sarana dan prasarana, manajemen tenaga kependidikan dan lain sebagainya. Manajemen peserta didik sangat penting dilakukan karena peserta didik merupakan objek dapat terlaksananya sebuah proses belajar mengajar dan proses transfer ilmu. Penerimaan Peserta Didik Baru (PPDB) merupakan sebuah langkah awal bagi sekolah untuk meningkatkan kualitas pendidikan. Dikatakan seperti itu karena jika tidak ada peserta didik maka tidak akan terjadi sebuah proses pembelajaran.

Selama ini masyarakat berasumsi bahwa sekolah yang bagus itu hanya berada di wilayah pusat kota. Sekolah-sekolah tersebut sering mendapat julukan sekolah favorit. Pada sisi lain, muncul juga istilah sekolah pinggiran, karena memang berlokasi di pinggir kota. Julukan sekolah pinggiran tersebut terlanjur melekat pada peserta didik, yang kemudian menyebabkan mereka yang memiliki kemampuan lebih dalam belajar (pintar) tidak berminat mendaftar di sekolah pinggiran yang lebih dekat dengan lokasi rumahnya. Padahal sistem pembelajaran dan fasilitas yang digunakan hampir sama. Pernyataan yang demikian akan menghambat kemajuan pendidikan, karena masingmasing dari masyarakat sekolah seakan sudah merasa pasrah dan tidak ada semangat untuk menciptakan sekolah yang mampu bersaing dengan sekolah lain yang berada di kota.

Perspektif itulah yang harus di ubah dengan adanya PPDB sistem zona. Dengan harapan adanya pemerataan dan peningkatan kualitas pendidikan di setiap daerah. Selaih itu, dengan PPDB ini penyebaran lulusan siswa di setiap sekolah di berbagai daerah diharapkan bisa merata. Dengan demikian, kedepan tidak ada lagi kekhawatiran kekurangan murid saat tahun ajaran baru tiba. PPDB sistem zona merupakan sebuah sistem yang dirancang untuk melakukan seleksi secara kewilayahan. Siswa lulusan tingkat SD atau sederajat yang berdomisili di wilayah tertentu dapat mrndaftarkan diri di SMP dengan radius terdekat. Sistem PPDB zona mampu memenuhi harapan dikalangan masyarakat yang tinggal di daerah plosok tidak harus menyekolahkan anaknya pada jarak yang amat jauh.

Penerapan sistem zona ini sangat mendukung upaya pemerataan dan peningkatan kualitas pendidikan. Hal ini karena setiap wilayah memiliki peserta didik baru yang 
hampir sama prestasinya sehingga akan menghasilkan lulusan yang merata dan setara kualitasnya. Selain itu dengan sistem zona dapat mengurangi berkumpulnya peserta didik yang pandai dari golongan ekonomi menengah ke atas pada sekolah-sekolah favorit. Peserta didik dapat berinteraksi dengan peserta didik lain yang berasal dari golongan ekonomi menengah kebawah dan kemampuan yang biasa, sehingga dalam suasana demikian bisa menumbuhkembangkan rasa kebineka tunggal ika antar peserta didik. Hal itu juga dapat berdampak pada penghematan biaya pendidikan karena biaya transportasi yang ringan

Sistem zonasi merupakan upaya pemerintah untuk mengurangi tajamnya jurang pemisah antara sekolah maju, favorit, mewah dengan yang sebaliknya. Diharapkan dengan hadirnya sistem ini semua peserta didik tidak di bedakan kaya atau miskin, berprestasi atau tidak. Semua peserta didik di harapkan mendapatkan akses pendidikan secara merata. Smua bisa belajar, menggali kemampuan, ketrampilan dan bakat yang di miliki. Sehingga dapat menyongsong masa depan yang lebih cerah dengan pendidikan. Jika pemerataan pendidikan sudah terjadi, maka semua sekolah akan menjadi favorit.

\section{METODE PENELITIAN}

\section{Jenis Penelitian}

Jenis penelitian yang digunakan dalam adalah penelitian lapangan (field research). Adapun pendekatan yang digunakan adalah pendekatan kualitatif dengan menggunakan desain penelitian studi kasus. Dalam buku Moleong menurut Denzim dan Lincoln pengertian penelitian kualitatif adalah penelitian yang menggunakan latar alamiah, dengan maksud menafsirkan fenomena yang terjadi dan dilakukan dengan jelas melibatkan berbagai metode yang ada.

\section{Lokasi Penelitian}

Lokasi penelitian ini bertempat di Sekolah Menengah Pertama (SMP) di Kecamatan Temanggung. Alasan memilih lokasi tersebut karena Penerimaan Peserta Didik Baru (PPDB) menggunakan sistem zona di Kecamatan Temanggung baru berlaku pada tahun ini sehingga menimbulkan perdebatan panjang di kalangan masyarakat. Hal yang demikian akan menarik sekali jika diteliti, sehingga dengan penelitian ini bisa 
memberikan sumbangan bagi pendidikan lebih lagi bagi dinas pendidikan kabupaten Temanggung.

\section{Metode Penentuan Subjek}

Pada penelitian ini, peneliti akan menggunakan snowball sampling. Snowball sampling ialah pengambilan sampel sumber data, yang pada awalnya berjumlah sedikit lama kelamaan menjadi besar. Hal demikian dilakukan dari jumlah sumber data yang sedikit tersebut dianggap belum mampu memberikan data yang lengkap. Maka perlu mencari orang lain lagi yang dapat menjadi sumber data. Dengan begitu jumlah sumber data menjadi semakin banyakatau besar. Seperti bola salju yang menggelinding yang semakin lama akan semakin membesar.

\section{Subjek dan Objek Penelitian}

Subjek dalam penelitian ini panitian program penerimaan peserta didik baru (PPDB) menggunakan sistem zona yang meliputi kepala sekolah, wakil kepala sekolah, kepala seksi kurikulum SMP dinas kabupaten Temanggung, orang tua dan peserta didik. adapun objek dari penelitian ini adalah PPDB menggunakan sistem zona dalam pemerataan dan peningkatan kualitas pendidikan yang memfokuskan pada SMP N 3 dan SMP N 5 Temanggung.

\section{Teknik Pengumpulan Data}

Teknik pengumpulan data pada penelitian ini menggunakan wawancara, observasi dan dokumentasi.

\section{Teknik Analisa Data}

Data dalam penelitian ini adalah kualitatif. Teknik analisa yang digunakan yaitu model interaktif dari Huberman dan Miles yaitu reduksi data, penyajian data, penarikan kesimpulan dan verivikasi data. 


\section{HASIL PENELITIAN DAN PEMBAHASAN}

Efektivitas mengandung arti keefektivan (effectiveness), pengaruh atau efek keberhasilan, kemajuan atau kemujaraban. Efektivitas adalah kemampuan untuk memilih tujuan yang tepat Efektivitas adalah tolok ukur yang memberikan gambaran seberapa jauh target dapat dicapai. Misalnya suatu pekerjaan diselesaikan melalui pemilihan cara yang sudah ditentukan sebelumnya, maka cara yang ditempuh tersebut bernilai efektif. Dari beberapa pendapat tersebut dapat disimpulkan bahwasannya efektivitas merupakan suatu ukuran yang menunjukkan sejauhmana pencapaian target. Kualitas dan kuantitas output yang dihasilkan.

Salah satu ruang lingkup manajemen pendidikan adalah manajemen peserta didik, peserta didik merupakan komponen penyusun yang sangat penting adanya. Menurut Baharudin dalam buku Kristiawan dkk manajemen peserta didik adalah upaya penataan peserta didik mulai dari masuk sampai dengan lulus sekolah, dengan cara memberikan layanan sebaik mungkin Hakikat peserta didik adalah objek dan subjek pendidikan yang memiliki fitrah, potensi dan kodrat tertentu.Di sinilah peran pendidik sangat di perlukan karena dengan adanya pendidik dapat membantu, mengarahkan, mengembangkan macam-macam potensi yang dimiliki oleh peserta didik dan membimbingnya menuju kedewasaan.

Mutu dalam pendidikan mencakup input, proses dan output. Input pendidikan yakni sesuatu yang ada karena diperlukan demi berlangsungnya suatu proses. Kemudian proses pendidikan merupakan berubahnya sesuatu menjadi sesuatu yang lain. Dan output pendidikan merupakan keluaran atau hasil yang diperoleh sekolah dari proses yang telah dilakukan. Oleh karena itu, mutu dalam dunia pendidikan dapat dikatakan lebih mengutamakan pada keberadaan siswa. Dengan kata lain program perbaikan sekolah dilakukan secara lebih kreatif dan konstruktif.9 Jika dilihat dari hasil pendidikan, sebuah pendidikan dikatakan berkualitas jika mampu melahirkan keunggulan akademik dan mampu mengembangkan potensi peserta didiknya.

\section{Gambaran Umum SMP 3 dan SMP 5 Temanggung}

SMP Negeri 3 Temanggung terletak di jalan Jendral Sudirman No.21, Jampiroso, Kabupaten Temanggung, Jawa Tengah. SMP N 3 yang terletk di Jampiroso ini memiliki batas wilayah Sebelah Utara berbatasan dengan Kelurahan Banyurip, Sebelah Timur 
berbatasan dengan Kelurahan Kertosari, Sebelah selatan berbatasan dengan Kelurahan Jampirejo, Sebelah Barat dengan Kelurahan Temanggung I. Kelurahan Jampiroso, tempat sekolah ini berada merupakan salah satu kelurahan di Kecamatan Temanggung yang berada di ibukota Kecamatan. Kelurahan ini berjarak $1 \mathrm{~km}$ dari ibu kota Kabupaten. Kelurahan ini memiliki luas wilayah 56.890 Ha dan berketinggian 606 m dari permukaan laut.

Menurut masyarakat, SMP N 3 merupakan salah satu SMP N favorit yang berada di Kabupaten Temanggung. Alasannya karena sekolah ini berada di jantung kota Temanggung. Sehingga masyarakat berbondong-bondong menyekolahkan anaknya di sekolah tersebut. Ini dapat ditunjukkan ketika penulis melakukan wawancara sederhana dengan masyarakat desa dengan pertanyaan mengapa mereka lebih memilih SMP N 3 daripada SMP N 5, merekamenjawab, "Letaknya strategis, transportasipun cenderung lebih mudah ditemukan. Dilihat dari segi kualitasnya atau nilai UN lebih tinggi daripada SMP N 5 yang berada di pinggir kota".

Pada tahun ajaran 2015/2016 pendaftar SMP N membludak hingga melebihi kuota. Pada SMP N 3, meski hanya menerima sebanyak 192 peserta didik namun telah menampung hingga 500 peserta didik dalam kurun waktu tiga hari. Calon peserta didik akan mendaftar ke sekolah di kota terlebih dahulu sebelum mendaftar ke sekolah di pinggiran. Selain pendaftaran yang membludak, ketika peneliti mengamati di lapangan, kebanyakan lulusan atau alumni dari SMP N 3 akan melanjutkan pada jenjang SMA yang notabenenya favorit juga.

SMP Negeri 5 Temanggung terletak di Walitelon Temanggung, RT/RW 1/7, Dusun Krikil, Desa/Kelurahan Walitelon Selatan, Kecamatan Temanggung, Kabupaten Temanggung, Jawa Tengah. Salah satu dari 25 desa/kelurahan di Kecamatan Temanggung adalah Kelurahan Walitelon Selatan, terletak di ketinggian $550 \mathrm{~m}$ dari permukaan laut dan berjarak $3 \mathrm{~km}$ dari ibu kota kecamatan Temanggung dan 2,5 km dari ibu kota Kabupaten. Kelurahan Walitelon Selatan terdapat 9 dusun yang terdiri dari 9 Rukun warga (RW) dan 25 Rukun tetangga (RT) dan terdapat 920 kepala keluarga. Secara geografis desa walitelon selatan berbatasan dengan bagian barat dengan Kecamatan Bulu, Tlogomulyo dan Tembarak, utara dengan Kecamatan Kedu dan Kandangan, timur Kecamatan Kaloran dan Kranggan dan selatan dengan Kecamatan Tembarak. 
Lokasi SMP N 5 yang berada di pinggir kota dan sarana transportasi yang sulit, merupakan masalah utama yang mengharuskan SMP N ini dipandang sebelah mata oleh masyarakat. Dilihat dari segi kualitas nilai UN, SMP N ini masih kalah dengan SMP N 3. Menurut pengakuan salah satu calon peserta didik tahun ini ketika peneliti melontarkan pertanyaan bagaimana jika kamu tidak diterima pada SMP $\mathrm{N}$ favorit di Kecamatan Temanggung? "saya akan sekolah di Kecamatan tempat saya tinggal (baca : luar Kecamatan Temanggung). kenapa tidak melakukan pendaftaran misalnya di SMP N 5, kan masih di Kecamatan Temanggung sama dengan SMP (.....) (baca : favorit) ? "daripada sekolah dipinggir kota lebih baik dalam kecamatan sendiri, akan lebih mudah transportasinya”. Hal yang demikian masih menunjukkan bahwa sekolah pinggiran masih kurang diminati oleh masyarakat baik dalam wilayah maupun luar wilayah. Menurut pengakuan dari bapak H selaku kepala sekolah "kita ini harus membangun pandangan masyarakat terhadap sekolah kita". Peningkatan dalam proses belajar mengajar akan terus dilakukan agar kelak dikemudian hari SMP N ini dapat bersaing dengan SMP N di kecamatan Temanggung.

\section{Efektivitas PPDB Menggunakan Sistem Zona Dalam Pemerataan Dan Peningkatan Kualitas Pendidikan}

Mengenai efektivitas PPDB menggunakan sistem zona di SMP N 3 masih berdampak negatif. Sesudah diterapkannya PPDB sistem zona mengalami penurunan diberbagai aspek yakni pada nilai dan peminat. Dimulai dari jumlah nilai terendah sebelum menggunakan sistem zona berjumlah 260.50 sedangkan setelah menggunakan sistem zona berjumlah 215.50. Selanjutnya pada jumlah rerata juga mengalami banyak penurunan dari sebelum digunakannya sistem zona berjumlah 266.36 namun setelah diterapkannya sistem zona menurun menjadi 252.95. Terlepas dari itu, setelah menggunakan sistem zona mengalami peningkatan pada jumlah nilai tertinggi. Sebelum menggunakan sistem zona jumlah nilai tertinggi hanya 293.50 selisih enam angka setelah menggunakan sistem zona yakni berjumlah299.50. Hal ini disebabkan karena peserta didik yang berasal dari luar zona bersaing ketat pada nilai UN. Diterapkannya sistem zona peserta didik dari luar wilayah hanya yang memiliki nilai paling tinggilah yang akan masuk pad SMP N 3. 
Penerapan sistem zona ini masih berdampak negatif juga pada SMP N 5. Pada tahun ajaran 2016/2017 sebelum menerapkan PPDB sistem zona, jumlah nilai terendah sebesar 129.00 dan setelah menerapkan PPDB sistem zona menjadi 118.00. Jumlah rerata setelah diterapkan zona juga menurun yakni dari 210.86 menjadi 203.55. Terjadi penurunan pula pada jumlah nilai tertinggi dari 272.50 menjadi 268.00. Sangat terlihat jelas penurunan drastis pada jumlah peminat pilihan pertama 145 peserta dan pilihan kedua sebanyak 64 peserta didik sebelum diterapkan zona. Setelah menerapkan sistem zona menjadi 91 peserta didik pada pilihan pertama dan 42 peserta didik dipilihan kedua. Adapun tingkat keefektivan jika dilihat menggunakan tolok ukur evektifitas menurut Duncan yakni terlihat pada tabel :

\begin{tabular}{|c|c|c|c|}
\hline \multirow[t]{2}{*}{ No } & \multirow{2}{*}{$\begin{array}{c}\text { Tolok } \\
\text { UkurEfektivitas }\end{array}$} & \multicolumn{2}{|c|}{ Nama Sekolah } \\
\hline & & SMPN 3Temanggung & SMPN 5Temanggung \\
\hline 1 & PencapaianTujuan & $\begin{array}{ll}\text { a. } & \text { Tingkat keefektivan } \\
& \text { PPDBmenggunakan } \\
\text { b. } & \text { Sistem zonadi SMP N } \\
& \text { inilebih tinggi } \\
\text { c. } & \text { Target perolehan } \\
& \text { pesertadidik sudah } \\
& \text { terpenuhi. }\end{array}$ & $\begin{array}{l}\text { a. Ketimpangan kualitas peserta } \\
\text { didik masih ada. } \\
\text { b. Masih kurangnyakelas/rombel } \\
\text { c. Mengalami penurunan drastis } \\
\text { padajumlah pendaftar }\end{array}$ \\
\hline 2 & Integrasi & $\begin{array}{l}\text { Tidak } \\
\text { mengalamikendalayangberar }\end{array}$ & $\begin{array}{l}\text { Kurangnya sosialisasi } \\
\text { yangmenyeluruh. }\end{array}$ \\
\hline 3 & Adaptasi & $\begin{array}{l}\text { a. Saranaprasaranayangdise } \\
\text { diakan sudah } \\
\text { terpenuhi. } \\
\text { b. Jaringannya tidak } \\
\text { bermasalah.Namun, }\end{array}$ & $\begin{array}{ll}\text { a. } & \text { Saranaprasaranasudah ada } \\
\text { b. Mengalami gangguan pada } \\
\text { jaringan internet. }\end{array}$ \\
\hline
\end{tabular}

Proses adaptasi PPDB menggunakan sistem zona ini ditempuh melalui proses sosialisasi. Dengan adanya sosialisasi diharapkan stakeholder bisa turut andil dalam memajukan dunia pendidikan. Sehingga kualitas pendidikan akan menjadi lebih baik tanpa adanya kesenjangan antar sekolah. Sehubungan dengan penerapan sistem baru, mungkin masih ada kerancuan dilapangan. Terlihat ketika peneliti melontarkan pertanyaan "Bagaimana respon orang tua dan peserta didik terhadap PPDB sistem zona?" 
"Penggunaan sistem zona ini tidak ada masalah ya. Masih kaget saja yang di daerah perbatasan. Pertama karena kurang pengetahuan orang tua. Kedua kurang mantapnya sosialisasi dari sekolah kami, sehingga peserta didik yang dari luar zona sedikit sekali yang mendaftar. Padahal biasanya peserta didik kami berasal dari SMP 2 yang tidak diterima”.

Respon dari adanya kejadian tersebut bahwa sekolah masih perlu mengadakan sosialisasi secara mendalam untuk sekolah dasar yang berada di dalam zona.

\section{KESIMPULAN}

Dari hasil pembahasan di atas dapat disimpulkan bahwa Penerimaan Peserta Didik Baru (PPDB) menggunakan sistem zona diterapkan di Kecamatan Temanggung dengan alasan merujuk pada peraturan pemerintah Kementrian pendidikan dan Kebudayaan mengeluarkan Permendikbud No.17 Tahun 2017 tentang PPDB TK, SD, SMP, SMA, SMK atau sederajat. Dalam permendikbud tersebut di atur mengenai sistem PPDB zonasi yang harus diterapkan sekolah dalam PPDB. Sekolah yang menerapkan sistem zona tersebut wajib menerima calonpeserta didik yang berdomisili pada zona terdekat minimal 90 persen dari total peserta didik yang diterima. Tempat tinggal calon peserta didik tersebut berdasarkan alamat yang tercatat pada kartu keluarga. Adapun radius zona yang ditetapkan oleh pemerintah daerah (pemda) sesuai dengan kondisi daerah tersebut. Selain itu pemerataan kualitas pendidikan dan mengatasi ketimpangan.

Dilihat dari segi sarana prasarana yang digunakan dalam penerapan PPDB sistem zona pada kedua sekolah, sudah terpenuhi. Pada SMP N 3 tidak ada kendala yang berarti pada jaringan internet, karena mengingat letak strategis sekolah yang berapa di pusat kota Temanggung. Namun berbeda dengan jaringan internet di SMP N 5. Letak sekolah yang berada di pinggir kota menyebabkan jaringan internet yang digunakan tidak begitu lancar. Sehingga sedikit memperlambat proses PPDB. Selain itu, sosialisasi yang dilakukan oleh SMP N 5 kurang mantap. Sehingga mengakibatkan kekhawatiran untuk calon peserta didik yang berada di daerah perbatasan untuk mendaftar Penerimaan Peserta Didik Baru (PPDB) menggunakan sistem zona di Kecamatan Temanggung belum berjalan efektiv. Hal ini ditunjukkan dengan masih adanya ketimpangan pada sekolah pinggiran yaitu SMP N 5. Ketimpangan ini ditunjukkan dengan kurangnya kelas/rombel pada PPDB sistem zona. Miris sekali ketika data 
pemenuhan kelas masih kurang lumayan banyak. Untuk SMP N yang berada di tengah kota tidak ada masalah dalam pendaftaran. Siswa dari dalam zona akan menyerbu SMP $\mathrm{N}$ favorit dulu sehingga untuk yang di pinggir kota akan menunggu sisa dari pendaftar yang tidak diterima pada SMP N kota.

\section{DAFTAR PUSTAKA}

Bungin, Burhan. 2012. Analisis Data Penelitian Kualitatif ; Pemahaman Filosofis dan Metodologis keArah Penguasaan Model Aplikasi. Jakarta : Raja Grafindo.

\section{http://krjogja.com/web/news/read/35792/Sistem_Zonasi_dalam_PPDB}

https://news.okezone.com/read/2015/07/01/65/1174427/pendaftar-smpn-favorit-ditemanggung- membludak.

Kristiawan, Muhammad dkk. 2017. Manajemen Pendidikan. Yogyakarta : Budi Utama. Moleong, Lexy J. 2015. Metode Penelitian Kualitatif. Bandung : Remaja Rosdakarya.

Mukodi. 2011. Pendidikan Islam Terpadu Reformulasi Pendidikan di Era Global. Yogyakarta : Aura Pustaka.

Nawawi, Barda. 2003. Kapita Selekta Hukum Pidana. Bandung : Citra Aditya Bakti.

Sugiono. 2011. Metode Penelitian Pendidikan Pendekatan Kuantitatif, Kualitatif, dan R \& D. Bandung : Alfa Beta.

Umar, Husein. 2003. Business An Introduction. Jakarta : Gramedia Pustaka Utama.

Zahroh, Aminatul. 2016. Total Quality Management Teori \& Praktik Manajemen untuk Mendongkrak Mutu Pendidikan. Yogyakarta : Ar-Ruzz Media. 